\title{
Effect of different land configuration on the yield of soybean (Glycine max L.)
}

Jitendra Singh, Archana Kumari, Rakesh Jain and Nitin Pachlaniya

Received : 05.10.2017; Revised : 20.02.2018; Accepted : 01.03 .2018

See end of the Paper for authors' affiliation

Correspondence to :

Jitendra Singh

Krishi Vigyan Kendra, KGNMT, Kasturbagram, Indore (M.P.) India

Email : jitendrasinghkgnmt@ gmail.com
-ABSTRACT : A field experiment was conducted during the Kharif season of 2014-15, 2015-16 and 2016-17 at KVK, Indore to study the effect of different land configuration on the yield of soybean. The experiment consisted of three treatments of land configuration, viz., $\mathrm{T}_{1}$ (FIRBS layout), $\mathrm{T}_{2}$ (Ridge and furrow layout), $\mathrm{T}_{3}$ (BBF layout), under RBD design with seven replications. Result showed that significant increase was observed in yield contributing characters viz., number of pods plant ${ }^{-1}, 100$ seed weight (g), seed yield $\left(\mathrm{q} \mathrm{ha}^{-1}\right)$ and harvest index (\%) in FIRBS layout as compared to ridges and furrow and broad bed furrow. The net return is the best index of profitability of soybean crop and higher net return per ha of Rs. 24699 was recorded for soybean crop under the FIRBS whereas lower net return per ha of Rs. 20808 was recorded under BBF land configuration.

- KEY WORDS : Soybean, Land configuration, Yield attributes

- HOW TO CITE THIS PAPER : Singh, Jitendra, Kumari, Archana, Jain, Rakesh and Pachlaniya, Nitin (2018). Effect of different land configuration on the yield of soybean (Glycine max L.). Internat. J. Agric. Engg., 11(1) : 135-137, DOI: 10.15740/HAS/IJAE/11.1/135-137. 